\title{
DIALOGIA, ALTERIDADE E LINGUAGEM DO PÁTHOS
}

\author{
DOS IMPREVISTOS DA HISTÓRIA À ESTRELA DA REDENÇÃO
}

Nilo Ribeiro Junior ${ }^{*}$

\section{RESUMO}

Em vista de abordar a temática que tem como objeto a dialogia e a lógica da proximidade, urge situá-la no cerne da problemática filosófica da alteridade, servindo-nos de algumas referências advindas da literatura contemporânea. Tais referências sugerem ao interlocutor de deixar interpelar pelos personagens, de modo a poder realizar uma espécie de desencantamento com relação às formas de magia que estão a impactar a contemporaneidade associadas aos imprevistos da história como novas formas de desprezo do outro. Trata-se, em seguida, de propor alguns matizes de cunho histórico-filosófico com o escopo de aprofundar o que denominamos de figuras da alteridade advindas das metáforas do desastre e da estrela da redenção que se delineiam no contexto da filosofia contemporânea e que encaminham a reflexão da dialogia à nova impostação da linguagem avessa à violência contra o outro.

PALAVRAS-CHAVE: Pensamento. Linguagem. Ética. Alteridade.

\section{ABSTRACT}

In order to address the theme of dialogism and the logic of proximity, it is necessary to place it at the heart of the philosophical problem of otherness, serving us with brief reports of contemporary literature. They suggest to the interlocutor to allow them to be challenged by the characters, so as to be able to perform a kind of disenchantment with the forms of magic that are impacting the contemporaneity associated with the unforeseen of the story as new forms of contempt for the other. It is then a matter of proposing some historical-philosophical nuances with the scope of deepening what we call figures of otherness arising from the metaphors of disaster and the star of redemption that are delineated in the context of contemporary philosophy.

KEYWORDS: Thought. Language. Ethics. Otherness.

\section{INTRODUÇÃO}

Vivemos em um mundo cada vez mais marcado por uma espécie de enfeitiçamento que tende a obnubilar nossa mente. E, se associarmos a nossa mente ao modo de um pensamento inseparável da existência e da ação humana, é possível antecipar que essa magia consiste na incapacidade de escutar/responder à voz de outrem que vem da outra margem. Neste artigo, procuramos pontuar algumas questões de fundo que levam a vincular a ideia de dialógica à

\footnotetext{
* Doutor em Filosofia pela UCP - Universidade Católica Portuguesa. Professor de filosofia contemporânea na FAJE - Faculdade Jesuíta de Filosofia e Teologia. E-mail: niloribeiro@ unicap.br.
} 
alteridade a fim de repensar outra perspectiva para lidar com o mal-estar gerado pelos imprevistos da história, tendo em vista estabelecer interfaces entre a dialogia e o fim da violência contra o outro. Antes, contudo, vale recordar que nossa investigação não segue uma linearidade cronológica, mas se deixa guiar por uma abordagem sincrônica ou em certo sentido elíptica a respeito da problemática de fundo.

Há uma espécie de sedução própria de nossa denominada cultura imunitária que nos isola do contato com o "de fora", com o estrangeiro, a ponto de nos tornar pernósticos frente à diferença de outrem que não se submete à lógica do Mesmo. Em contrapartida, a relação com outro pode nos desenfeitiçar, afinal a dialogia se apresenta como sendo uma lógica ilógica de gratuidade, ou, se quisermos, da ordem da inutilidade porque diz respeito à hospitalidade de outrem. Trata-se de um acolhimento "tal qual uma liturgia, isto é, como uma ação a fundo perdido", (LEVINAS, 2009, 1988a, p. 34) preocupada em construir altares para outrem, o que se supõe a descida desses pedestais linguístico-egológicos tão endeusados pela nossa cultura da doxa exaustiva dos hipertextos.

Portanto, nossa investigação não pretende entregar-se à assepsia dos discursos politicamente corretos porque, se de um lado a dialógica evoca uma nova estética da Altura ou da bondade na relação com Outrem, como previu Levinas (2009, p. 57), por outro ela se refere à densidade, à gravidade e ao escândalo da vida nua que está em jogo quando se usurpa a proximidade de outrem a fim de mimetizá-la em benefício próprio e, quem sabe, de se praticar o absurdo dos sacrifícios humanos (AGAMBEN, 2008, p. 76).

\section{O MAL-ESTAR DA CULTURA CONTEMPORÂNEA E DA DIALÓGICA DO PRÓXIMO}

Faz-se mister evocar, inicialmente, aquilo que nos parece contundente ou hiperbólico subjacente à problemática da dialogia em nossas denominadas sociedades de indivíduos, isto é, o desconforto visceral que experimentamos na contemporaneidade, não apenas por conta da perda de sentido do humano, mas, sobretudo, pela perda do lugar (topos) e da linguagem (tropos) inaugurados pela "visitação do outro" (LEVINAS, 1988b, p. 23).

Ora, no advento do outro que se faz próximo se processa um acontecimento inédito. Sua epifania avessa ao espetáculo carrega consigo o caráter kairológico por configurar-se como um tempo imemorial de um evento que não acaba de acontecer, isto é, que não passa, dado as marcas ou "afecção suscitadas pelo outro e a nos deixar desarmados, sem defesa, 
diante de seu Rosto" (LEVINAS, 1988b, p. 62). Ao nos atingir ou cair sobre nós como um desastre, vindo do alto, de baixo, de um não lugar para um outro não lugar - sem ter lugar onde reclinar a cabeça - ele nos expropria, nos esvazia e solicita de acolhê-lo em nossas provisórias moradas.

Entretanto, esse mesmo outro que suscita um estranhamento quase profético/poético em nossa existência, que implode nossas tentativas de compreensão por meio de conceitos frios, deflagra uma reação, uma antipatia que suscita um "desejo mimético que, num toque de mágica vai da admiração à perseguição para desembocar no ódio e na eliminação do outro" (GIRARD, 2009, p. 4). Afinal, o outro se apresenta como absolutamente outro em sua outreidade e, porque escapa de nosso controle, provoca a fúria e o assassínio do outro.

Esse mal-estar e a sensação de desconforto experimentados pela catástrofe indissociável do esquecimento do outro provocam reações mais inesperadas e distintas possíveis na atualidade, a ponto de deflagrar enfrentamentos também muito diversos nos sujeitos, nos grupos, e na vida política, religiosa e cultural contemporânea. E isso repercute diretamente na maneira como a questão da dialogia é acolhida ou banida de nosso horizonte existencial. Nessa esteira, a partir de uma constatação não imaginária, podemos afirmar que vivemos em tempos sombrios e que, paradoxalmente, provamos daquilo que Maurice Blanchot associa a um (des)astre. O pensador trata de associar "o desastre ao Porvir de modo a se poder transgredir, por meio concreto da literatura/escritura, a sensação da perda dos fundamentos pela sensibilidade ao novo céu aberto por outrem" (BLANCHOT, 1980, p. 21).

O desastre assume, portanto, uma positividade exatamente como maneira de cavar uma metafísica outramente. Ao invés de remeter-nos para o céu estrelado da Metafísica da filosofia ocidental, evoca uma "estrela cadente que vem cair sobre o alto de nossas cabeças" (BLANCHOT, 1980, p. 30). Esse desastre poderá nos jogar na/para a relação com outro como lugar de uma estranha transcendência descendente ou (trans)descendência. Longe de nos seduzir pela busca do tempo perdido, tratar-se-ia de um acatamento de um passado imemorial graças à passagem de outrem que não acaba jamais de passar. Essa maneira de pensar outramente propugnada pela poética de Blanchot parece instigante e deverá retornar mais adiante quando estabelecermos uma proximidade entre o desastre e a Estrela da Redenção (1929) em Franz Ronsenzweig.

Entretanto, há de se ter em mente uma outra perspectiva, levando-se em consideração a abordagem advinda do registro simbólico psicanalítico, explorado por outro pensador francês, Pierre Gisel, para o qual o sentido positivo do desastre reforça aquele do pensamento 
de Blanchot. Ele evoca, portanto, a "destituição da sideração, ou melhor, a desorbitação de alguém em torno de um astro, dando origem ao (de)sidério ou ao desejo humano" (GISEL, 2009, p. 43). Ora, o desejo arranca o indivíduo da satisfação imediata da existência que gira em torno de um lugar protetor, introduzindo em seu seio uma fome insaciável do outro que, “de próximo se faz estranho a fim de ser buscado pela distância infinita” (LEVINAS, 1988a, p. 66).

Esse desejo, pois, supõe um deslocamento por conta da aproximação daquele que está fora do alcance, fora de lugar. Essa fome que o orienta para as alturas, para o que está separado, o santo, ao mesmo tempo o desorienta ao ver desfazer seus projetos diante da urgência de se fazer próximo e desejante de cuidar da precariedade do outro decaído ou desfigurado. Entretanto, o homem desejante prefere viver vagando perdido no espaço sideral em torno do gozo ao invés de dar-se ao árduo trabalho do Desejo do outro (LEVINAS, 1988b, p. 73).

E se o Desejo tende a ser engolido por um desses "buracos negros" que espreitam as estrelas a fim de lhes sugar sua energia vital e de fazê-las evaporar no espaço sideral, o mesmo ocorre com nossas sociedades entregues à sedução do gozo de toda sorte que se oferece de forma insistente e cada vez mais atraente aos apelos sensoriais. Isso tende a forjar sempre novas demandas, e estas acabam por esvaziar os sentidos que somente o sentido dado pelo desejo do (in)desejável outro pode rearticulá-los em torno da ética (LEVINAS, 1988a, p.30).

É como se nessa ótica, a catástrofe humana na contemporaneidade reeditasse com o devido requinte de realismo o Mito adâmico, narrado pelo Livro do Gênesis. Isso porque a humanidade já não se basta na consumição e no saborear os frutos da "árvore da vida" como "uma forma ingênita de viver segundo a sabedoria que a inabita". Ao contrário, a humanidade prefere se satisfazer, ainda que a duras penas, com os frutos da "árvore do conhecimento", seduzida pela lucidez da visão de uma ciência do bem e do mal. Esta semeia no coração humano "a competição com o outro em nome de um poder-saber movido pela suspeita de que o outro lhe tolhe o direito de saber-gozar" (GISEL, 2009, p. 56).

Essa catástrofe, recorda o filósofo franco-judeu Emmanuel Levinas, se configura como um fenômeno epocal posto a olhos nus pela Shoah. O Holocausto colocou radicalmente em questão aquele fundamento inconcussum estruturante do Real que, desde a era clássica passando pela medieval para desembocar na modernidade, fora erigido como bastião da verdade e gênese do sentido. O genocídio praticado contra judeus, ciganos, homossexuais, e 
para a ironia do destino, contra aquela estirpe de "inumanidade muçulmana", isto é, aquela "considerada como cadáver ambulante marcado pela indignidade da própria morte", escancara a contradição da Metafísica (AGAMBEN, 2008, p. 76).

Dito ainda de outra forma, e talvez mais preocupado em descer às filigranas da catástrofe na ótica de uma Filosofia Política, Franz Ronsenzweig insiste que a crise epocal não se deve à Metafísica propriamente dita, mas à sutil tentação que dela decorre e da inequívoca queda à qual se entregou a História da Civilização e o pensamento ocidental. O filósofo explica que a civilização greco-romana ao longo de sua história milenar tem oscilado entre a ênfase na unificação do sentido em torno da Natureza no contexto da cosmologia e da filosofia antiga; “ou” em Deus, na perspectiva medieval da cristandade, “ou” no Homem, com o advento do antropocentrismo e da consecução dos humanismos derivados daquele.

Nesse caso, urge apontar para a questão hiperbólica que a acompanha pois, apesar de seu poder de unificação do real, o fato é que a oscilação entre esses princípios deixa entrever, curiosamente, a derrocada da Metafísica, devido à constante ascensão do pensamento. Esse pensamento a faz desconfiar da diversidade de sentidos, uma vez que ele, como "o" pensamento, a convence de manter viva a suspeita diante da diferença, sinal de incerteza e de equívocos em um mundo desorientado.

O pensamento metafísico-político não suporta a ideia da pluralidade do Ser, uma vez que isso significaria ter de admitir a negação do princípio da contradição estruturante do imaginário da filosofia greco-romana. Nesse caso, a diversidade parece se opor à universalidade. Eis, pois, que face à tentação do uno de Parmênides, a Metafísica ocidental acabou por gerar um encantamento em torno de seu propósito de pensar o todo "ou" em nome da cosmologia, "ou" em nome da teologia "ou" em nome da antropologia sendo que um princípio deve, necessariamente, excluir os demais.

Em suma, a magia consiste exatamente na totalização do pensamento. Essa magia tende a banir de seu horizonte outros sentidos que não passem pelo crivo da unidade de sentido dado pelo pensamento unívoco. E a prova mais contundente dessa totalização do ser, segundo Rosenzweig, se verifica na ideia de Estado moderno prussiano. Já desde o século XIV a Política alemã reivindicara para si a condição de um Estado liberal e, portanto, um estado com a pretensão universalista. Entretanto, a filosofia política e suas análises levam a constatar com assombro a ideia de que "o estado alemão fora movido por um pensamento unívoco, nacionalista, edificado à sombra dos interesses do particular e legitimado pela pretensão de totalidade segundo o Espírito absoluto" (ROSENZWEIG, 2003, p. 11). 
Em termos reais, o pensamento unívoco exige, forçosamente, a exclusão do outro sentido, isto é, a exclusão da pluralidade de sentidos e, pior, redunda na exclusão do outro, uma vez que impossibilita o desastre positivamente concebido aos modos de Blanchot, pois somente um desastre dessa natureza permite (re)ssignificar os antigos sentidos a partir de baixo, do âmago das relações com outrem, bem como de dar vazão a outros sentidos absolutamente outros, isto é, aqueles outros que irrompem do sentido ético da acolhida de um outro em meio à catástrofe e aos imprevistos da história.

\section{DA MAGIA DA NECROFILIA AO PENSAMENTO OUTRAMENTE}

Apesar da constatação sombria que deriva da catástrofe ou da perda de sentido na contemporaneidade, há outra maneira de se pensar a humanidade do homem, o mundo e os deuses. Há uma classe de homens tomada por um impulso vital, e mesmo sob influxo da sedução da morte que atinge a todos, acredita e se entrega à (u)tópica maneira de viver inspirada, não pela lógica do gozo, mas por outra maneira de conceber a existência graças à "sensibilidade à flor da pele com que se deixa tocar pelo outro" (LEVINAS, 2011, p. 45).

Ao modo do páthos da imediação da proximidade pathética não é incomum encontrar um homem que toma a relação com o outro como lugar da paixão, seja como amor e padecimento, seja como empatia apaixonada mesmo tendo que lidar continuamente com a antipatia suscitada por outrem. Eis que, nessa outra ótica, a positividade do desastre ao qual se referia Blanchot contempla um Por-vir para a humanidade porque se trata de fazê-la (des)orbitar ou desejar viver da relação inexcusável com o próximo/distante que está sempre por abrir uma porta inesperada como sentido ético.

Porém, se a imediação patética dessa relação em princípio se expressa no face a face ou no corpo a corpo, ela ultrapassa de longe o toque, o tato, graças a um contato cuja lógica é da ordem de um meridiano, como recorda Levinas ao comentar a obra $O$ meridiano de Paul Celan (LEVINAS, 1976, p. 60). Na Geografia, um meridiano é qualquer semicírculo máximo que contenha os dois polos de um planeta. Nesse caso, o meridiano divide a Terra como se ela fosse uma laranja com gomos. Cabe ressaltar que o meridiano vem acompanhado de uma curvatura cujos polos destinados a se encontrarem mantêm certa abertura porque não se completam como num círculo. Do ponto de vista poético, a relação com outrem é equiparada a um poema-meridiano tanto pela curvatura como pelo semicírculo em torno da sensibilidade, que esse contato com o outro está sempre a supor. 
A partir do Sensível ético, trata-se de vislumbrar o meridiano como "na carícia", (LEVINAS, 2009, p. 99) em que um olhar acaricia o outro ou que a tonalidade da voz ao dizer um bom-dia diz sempre mais do que um Dito linguístico, cuja estrutura em princípio poderia ser analisada do ponto de vista de uma Linguística da língua e/ou de uma Linguística do discurso. Entretanto, para a sensibilidade meridiana, tanto a carícia como um dizer, ambos dispensam o toque e a visão do interlocutor da fala. Do ponto de vista da linguagem, assevera Levinas, o meridiano em Paul Celan evidencia aquilo que é fundamental na linguagem do contato com o outro e tantas vezes esquecido por conta da hermenêutica ou do estruturalismo linguístico.

Dito de outra forma, a relação com outrem, quer pela figura da tangente, quer pela figura do meridiano, permite associar a palavra à inter(pele)ação a um Enigma pelo fato de o outro jamais poder ser tocado ou alcançado, dado a curvatura e a abertura que a interpelação evoca. Ela suscita um declínio reverencial diante do outro sem demandar sequer um "aperto de mão" como se somente esse fosse expressão do contato. Portanto, se a religião sempre reivindicou para si a reverência diante do sagrado, aqui, na relação com outrem, a declinação se descreve como dever, não por conta do respeito e da obrigação ritualista devidos à sacralidade dos deuses, mas graças à inspiração que a santidade do outro sopra aos ouvidos daquele que se expõe à sua voz. Nessa esteira, o Santo jamais se deixa mesclar pelo sagrado, porque o Rosto é sempre da desordem de um "de fora", de um porvir e não de um mero devir. É, pois, devido à novidade introduzida pela relação ética com o outro que o desastre de fato deverá ocupar um lugar poético-metafórico capaz de liberar-nos da necrofilia que acompanha a catástrofe da cultura contemporânea.

Soma-se a isso o fato de o outro jamais poder ser aprisionado no contato, pois ele irrompe como alguém que, tendo vindo, já partiu. Os vestígios ou traços de um Rosto não deixam rastros porque sua passagem se dá à noite. Ele vem como num estranho adeus e, porque não dizer, sua visitação, cuja proximidade pathética é tangencial, provoca naquele que lhe dá passagem um adeus aos ídolos e às idolatrias que visam apagar o outro pela memória ou que cultuam uma poética memória de outrem sem que ela expresse um apelo radical ao fim da violência contra a vitimização do Rosto.

Nessa lógica do adeus inaugurada por um Rosto, mesmo quando outrem é silenciado pela atrocidade do banimento do assassínio, sua voz faz vibrar todas as fibras das entranhas do corpo-maternal de alguém que, tendo sobrevivido ao massacre, como no caso da escritora 
africana Scholastique Mukasonga que, diante do aviltante genocídio de Ruanda, se sabe testemunha ética de um Rosto.

Trata-se aqui das narrativas outramente de um pensamento desenfeitiçado como bem expressa sua obra Baratas - cujo título provoca-nos com a mesma força profética das larvas evocadas na obra $E$ isto um homem? do pensador judeu Primo Levi (1988). Essas histórias fora da História contam com a inspiração capaz de provocar no ouvinte/leitor uma fissura ética que nenhuma poética daria conta de conter. Pois trata-se da retidão de um poema austero no qual o sujeito no acusativo pode se dizer: Eis-me aqui para suportar a eternidade de seu Nome. Esse poema de um corpo-padecido dá origem a uma forma sui generis de (ex)critura santa porque calcada na sensação e no dizer ético, antes que na percepção e seu dizer estético ou dizer ontológico que tende a sacralizar o Ser selvagem em detrimento do Rosto.

É como se a condição da barata assumida e testemunhada pela própria escritora tivesse feito ressurgir das cinzas as incontáveis outras baratas ou os milhões de larvas humanas do povo tutsis, barbaramente varrido do Congo por um pesticida que só mata seres humanos.

Todas as noites meu sono é abalado pelo mesmo pesadelo. Sou perseguida, escuto uma espécie de zumbido que vem em minha direção, um barulho cada vez mais ameaçador. Não me viro. Não vale a pena. Sei quem me persegue... Sei que eles têm facões... Às vezes, também, aparecem minhas colegas de classe... Agora, estou correndo sozinha, sei que vou cair, que vão me pisotear, não quero sentir o frio da lâmina sobre o meu pescoço, eu... Acordo. Estou na França. A casa está em silêncio. Meus filhos dormem em seu quarto. Tranquilamente. Acendo o abajur de cabeceira. Vou até a sala e me sento em frente a uma mesinha. Sobre ela há alguns objetos e uma foto, uma foto de casamento, o casamento e Jeanne, minha irmã caçula. Estão todos reunidos: a noiva em seu vestido branco, que eu mandei fazer em um alfaiate paquistanês em Bujumbura; Emmanuel, o noivo, apertado em seu terno; meu pai, com a canga branca amarrada no ombro; minha mãe, muito frágil, envolta em sua roupa domingueira. Procuro Antoine, meu irmão mais velho, e seus nove filhos, minha irmã Alexia e seu marido, Pierre. Procuro Judith, a mais velha da família que fez a comida das núpcias; e todos os sobrinhos, todas as sobrinhas, e todos de Nyamata, de Gitwe, de Gitagata. Eles vão morrer. Pode ser que já saibam disso.

Onde estão eles hoje? Na cripta memorial da igreja de Nyamata, crânios anônimos entre tantas ossadas? Na selva [brousse], sob os espinheiros, em uma fossa que ainda não veio a público? Copio inúmeras vezes o nome deles no caderno de capa azul, quero provar a mim mesma que eles existiriam, pronuncio seus nomes um a um na noite silenciosa. Sobre cada nome devo definir um rosto, pendurar um retalho como lembrança. Não quero chorar, sinto as lágrimas escorrerem pelas minhas faces. Fecho os olhos, esta será mais uma noite sem sono. Tenho muitos mortos a velar. (MUKASONGA, 2018, p. 7-8).

Essa maneira de viver e de pensar outramente sem se esquecer de Jeanne, Emmanuel, Alexia, Pierre, Judith como o faz Mukasonga, refere-se ao que Viveiros de Castro (2015, p. 
23), o grande antropólogo brasileiro, dizia em sua obra Metafísicas canibais, a respeito de um pensamento do outro, ou de "um pensar que não dispensa jamais a companhia dos outros". Trata-se de um pensar com outras-mentes que, por serem diferentes, desmentem ou desmascaram continuamente a tentação de não mais pensar tragado pelo mutismo do gozo ou quem sabe pensar segundo a mesmidade dos algoritmos, isto é, de perseverar no pensamento do homem, do mundo de deus, como se eles fossem forças abstratas, antinômicas, concorrentes (ROSENZWEIG, 2003, p. 22).

\section{A ESSÊNCIA ÉTICA DA MANIFESTAÇÃO E A OUTRAMENTE METAFÍSICA}

Na contramão dessa postura repleta de magia, pensar outramente significa mover-se na direção de um desencantamento da necrofilia contemporânea, isto é, de um movimento contrário a essa espécie de cultivo da pulsão de morte - instigada pelas antinomias ou pela ênfase no Neutro do ser - e deixar que se aproximem os desiguais, os diferentes; de dar vazão à assimetria e à diacronia instauradas pela irrupção do outro quando da relação com ele. Isso supõe, portanto, fazer com que o sentido ético da proximidade enquanto páthos presida todos os outros sentidos (ROSENZWEIG, 2003, p. 311).

Em outras palavras, trata-se de interromper a lógica da imposição desse "ou" daquele princípio ou aquela outra lógica da socialidade do Neutro em torno da Razão, do Ser, da Linguagem, da Política que sacrifica a unicidade em nome do todo. Afinal, essas posturas esvaziam a carnalidade, isto é, a essência concreta tanto do homem, do mundo, como dos deuses antigos feitos dessa "massa da barata" e que, portanto, os fazem resistir aos conceitos e à magia do pensamento ontológico a partir do qual tudo receberia sentido.

A propósito da questão da essência, cabe ressaltar, nesse contexto, ela diz respeito à ordem da "essência da manifestação ou da fenomenalidade do fenômeno" (LEVINAS, 2002, p. 125) que recusa terminantemente a tematização, a representação e a conceptualização de Deus, do homem e do mundo porque se trata de algo vivido, sentido, amado, padecido, doído, e não daquilo que é visto, compreendido, descrito, segundo a fosforescência do Ser.

Nessa ótica, a maneira de interrupção dos discursos totalizantes supõe uma metafísica outramente: aquela que deixa falar outrem pela proximidade do páthos de sua voz antes do que pela evocação de sua presença ou de sua imagem que evoca a plasticidade do fenômeno e com ele a sedução e a tentação de rostificar um Rosto incontextualizável. 
Outrossim, a essência diz respeito ao que é da ordem do concreto mais real do que a existência tão enaltecida pela viragem onto-fenomenológica do pensamento contemporâneo (ROSENZWEIG, 2003, p. 309). O acesso à essência se dá, portanto, de maneira indireta, diacrítica, na contracorrente do pensamento direto suscitado pelas ideias claras e distintas, pela ênfase na clareira e nas paisagens, no aparecer e no temporalizar do fenômeno a partir do qual se é tentado a transformá-lo em conceito depois de ter passado pela existência (LEVINAS, 2009, p. 84).

Ao contrário, na fenomenalidade da proximidade com outrem "a essência é da ordem da sensibilidade ética" (LEVINAS, 2009, p. 99). Por isso a essência enquanto páthos se recusa à visão; não aparece no mundo, na cultura e na História; não é da ordem da facticidade do ser-em-mundo, ou da significação dada pelo contexto a partir da qual tudo se define, tudo se compreende e do qual a existência recebe seu sentido ontológico. Ao invés, a essência é da ordem "da significância do vestígio; ela se significa a si mesma na relação ética com outrem" (LEVINAS, 2009, p. 94). Ela se apresenta a si mesma retirando-se de cena, e o faz no Dizer ético daquele que se diz movido pelo silêncio de um corpo tombado de outrem, como bem o narra Mukasonga quando se refere às baratas humanas: "Eu não apenas era tutsi, mas uma inyenzi, uma dessas baratas lançadas para fora da Ruanda habitável, talvez para fora do gênero humano.” (MUKASONGA, 2018, p. 87).

Se, por um lado, a barata evoca a vida nua (AGAMBEN, 2008, p. 71) e sua insignificância como a de um inseto dos que mais provocam repugnância no ser humano, por outro, a barata humana exalta aquilo que é não tematizável a respeito do humano, e que não cabe nas categorias estéticas do humanismo clássico ou da metafísica moderna, como já fizera Kafka (2000, p. 5) no clássico Metamorfose.

Por todas essas considerações provenientes da literatura e da filosofia como as que evocamos há pouco, se poderia estender o pensamento de outramente metafísica às metafísicas negras, metafísicas periféricas, metafísicas trans tal como nos inspira a pensar a Metafísica das baratas humanas de Mukasonga. Urge, pois, dar voz à essência da manifestação do humano que só a voz dessas alteridades pode fundar contra toda a pretensão dos pós-humanismos que derrapam diante da inenarrável miserabilidade humana que supõe a ética.

Nessa ótica, pensar outramente significa escutar vozes outras que, na contracorrente do apelo à escuta do Ser, estão a nos desenfeitiçar da fixação no tempo da existência e no lugar do ser que se oferece à compreensão. As vozes dos outros nos alteram, nos abrem, nos 
perfuram e nos deslocam de uma certa ordem, mesmo aquela própria da desordem do caos, de modo a nos fazer atravessar para uma terceira margem. Nela, o porvir se anuncia como umbem-vindo-para-nós e um-terceiro-conosco que faz eclodir um reino que não é da ordem de devir (da vida), mas de um advir (outro).

\section{PENSAR MAIS DO QUE SE PENSA E O FIM DA NECROPOLÍTICA}

O pensar outramente não se contenta com a desconstrução do sujeito como propugna o estruturalismo linguístico e tampouco concorda com a exaltação do Dasein da ontologia. Ao contrário, ele leva a sério a possibilidade de ressignificar o Eu fora de si graças à imediação patética da relação com os outros; de pensar os deuses a partir da vida da qual jamais se distanciam e, assim, "os tirando do crepúsculo dos deuses; de pensar o mundo a partir de sua própria inteligibilidade que transgride o estatuto das ciências empírico-formais ou da razão instrumental" (SOUZA, 2010, p. 48).

Em outras palavras, trata-se de um pensar outramente metafísico que pensa sempre mais do que pensa quando dá passagem a que outras mentes invadam os sentidos (ver, escutar, tocar, saborear) por uma Sensibilidade ética aquém do ser selvagem. Há de se enfatizar que o pensar [com]outras-mentes não significa substituir os velhos fundamentos por outro, isto é, por uma alteridade abstrata, nem significa perder-se no caos, mas em perder-se a fim de que outros ganhem numa forma de vida ética (anti)necrológica e (anti)sacrificial.

Esse perder-se supõe uma sabedoria do amor que diz adeus às novas idolatrias do saber de toda sorte que pretendem nos encantar pela lógica dos números e nos convencer pelas estatísticas do monetarismo do dinheiro, do "sobe e desce" das bolsas de valores, da produção em série ilimitada; enfim, que seduzem pela magia da mimética multiplicação e acumulação de bens. Ao invés, "a sabedoria do amor vive do milagre de se ter o pão arrancado da própria boca" para alimentar o próximo entregue à radical vulnerabilidade de um corpo morrente que clama por amor e justiça contra toda segurança humana na existência sem essência (LEVINAS, 2011, p. 45).

\section{DA CATÁSTROFE À ESTRELA DA REDENÇÃO}

Nessa altura da investigação resta-nos por retornar ao pensamento de Rosenzweig a fim de focar a percepção do Real estruturado em torno da figura da estrela que o pensador, 
curiosamente, não poupa esforços para associá-la à redenção. Não se trata de uma estrela qualquer, mas de uma estrela da redenção, aliás, título da obra de 1929 que consagrou o pensamento do grande filósofo judeu na atualidade. Por sua vez, essa estrela não se dissocia de um Rosto e da respectiva lógica dialógica tal como estamos a procurar em meio à catástrofe. Se a última prefigura o fim trágico da queda dos astros, um cataclismo de traços apocalípticos, o Rosto como uma estrela pode inaugurar um Porvir, isto é, uma espera escatológica movida por um desejo de se juntar ao Rosto na instauração do messianismo ou do reino a advir por meio da justiça e do amor num mundo destroçado pelo horror da morte.

Compreende-se a partir dessa ótica que o desastre evocado por Blanchot se aproxime do sentido da estrela em Rosenzweig. Ambos se referem ao "de fora" ou ao advir, ao Porvir que somente "a essência da manifestação na proximidade ético-pathética do próximo" dá acesso e que se apresenta como maneira de um resistir à catástrofe (ROSENZWEIG, 2003, p. 308). Diferente, pois, de um pensamento circular em torno do Uno que se fecha sobre si, a figura de um Rosto inaugura um pensamento estelar, excêntrico, sem síntese, (anti)dialético por excelência, uma vez que sua positividade em torno do Porvir não se deixa acompanhar pelo imaginário do binário da matemática clássica "que oscila entre o Zero/Um". Diga-se de passagem, esse imaginário está a inspirar "a lógica do ser" (to be or not to be) da ontologia ocidental desde sua tenra idade nos pré-socráticos até aos nossos dias (ROSENZWEIG, 2003, p. 43).

Nos antípodas da ontologia, a estrela segue uma outra lógica matemática, a do cálculo diferencial, que lhe serve de imaginação criativa para se pensar a partir da aproximação tangencial com a alteridade (dos polos da estrela) sem ceder às antinomias que subjazem especialmente à filosofia moderna do Espírito de Hegel e à ontologia contemporânea de Heidegger. Essas antinomias, segundo Rosenzweig, têm sua razão de ser em dois motivos principais. O primeiro se deve ao fato de o pensamento circular pensar a partir do abstrato, isto é, de abstrair o concreto, o corpo, a carnalidade de que somos feitos. Ora, o concreto que nos afeta e nos diz respeito interdita qualquer contraposição de uma coisa a outra.

A singularidade das coisas únicas - do homem - do mundo e dos deuses - não permite destituí-las de um ser-uma-alguma-coisa e de se poder resistir ao pensamento que as reduz às generalidades. O fato é que ao tratá-las dessa maneira, o pensamento circular tende a discursar a partir da linguagem calcada em conceitos genéricos de "o" homem, "o" mundo, "o" Deus e, assim, sucessivamente, de modo a distanciá-las daquilo que nos toca realmente. Segundo o filósofo esse pensamento acompanhado de sua lógica é um engodo e provoca um 
encantamento porque nos faz erigir um pensamento unívoco segundo "a Razão idolátrica que nega a acolhida do outro, do diferente, do desigual outrem" (SOUZA, 2010, p. 37).

\section{DO HOMEM SEM CORPO AO ROSTO SINÉDOQUE DA CARNE}

E, portanto, só poderemos evadir dessa magia quando defrontarmo-nos com a "morte" real porque ela não se deixa capturar pelo conceito "morte", como sendo "a" morte a partir da qual tudo se pensa, isto é, a partir do Nada da morte que é um nada nessa esteira do pensar circular que vai do universal passando pelo particular para chegar ao universal concreto.

Nesse sentido, a morte interdita a idolatria porque na morte real um Rosto vai à morte. Afinal, a morte real não pode ser mera representação (ídolo) de algo que suscita o pensamento e, por sua vez, nos ilude como se nós dispuséssemos de uma "ciência da morte" e por meio desta exercêssemos um domínio sobre aquela. Isso se revela como um ledo engano, ou melhor, um autoengano como se o imaginado e o pensado sobre a morte fosse o real. Bem ao avesso desse pensamento o fato é que a "vida nua" (AGAMBEN, 2008, p. 34), confrontada pela morte, refere-se imediatamente à morte de um corpo único "de ser-uma-alguma-coisa que morre" (ROSENZWEIG, 2003, p. 30).

Enfim, na contracorrente desse pensamento idolátrico em torno do Nada, trata-se de defrontar-nos com a morte única de cada um que morre nas guerras, nos genocídios e, atualmente, nas tanatofobias de gênero, de etnias, de negros, pobres e que, portanto, não pode ser igualada, neutralizada, universalizada ao Nada do conceito impávido e insensível da morte. Por sua vez, a morte real se apresenta como "uma" determinada morte de um Rosto de um ser-uma-alguma-coisa e que, portanto, se comparado ao Nada do conceito "morte", põe radicalmente em questão o pensamento sobre a morte/nada (ROSENZWEIG, 2003, p. 68).

Logo, a morte de alguém, de um Rosto humano, denuncia o escamoteamento do Espírito que pretende pensar a morte em detrimento da morte de um corpo-vivo que de fato foi e vai à morte todos os dias. Enfim, esse corpo muito preciso cuja voz se faz ouvir pela exposição desse um-ser-alguma-coisa de um corpo entregue à mortandade, faz ressoar-se no instante da duração do grito que se eterniza como presente para aquele que se depara com um moribundo, pois um Rosto sinédoque da carne denuncia a injustiça de que toda morte humana é cumplice.

Eis que a morte de um corpo único real sem subterfúgios interdita o Elogio à morte como horizonte de sentido que teria servido como mote para a Fenomenologia do Espírito de 
Hegel e seu pensamento da totalidade, na modernidade, bem como para a ontologia de Heidegger e seu pensamento anônimo, na contemporaneidade.

Ora, na perspectiva ontológica, defrontamos com a morte sem Rosto, porque marcada por uma certa gnose, um saber que prescinde da morte real, isto é, que pensa a morte como uma "possibilidade da impossibilidade" da existência. E a partir desse saber existencial calcado no ser-no-mundo, do ser jogado na existência, o pensamento nos lança ávidos para dentro da existência, conduzindo-nos a projetar a existência com sentido, a fim de dar sentido à (minha) morte. É, portanto, o Ser que mediatiza a reflexão existencial da morte dos existentes. Trata-se de pensar a partir de um ser que nunca morre porque ele se retira como terceiro excluído da morte real, assim como ele me faz preocupar e cuidar primeiro em dar sentido à minha morte, a prescindir da preocupação com a morte do outro, sempre referida ao Sentido do ser.

Contra essa visão necrológica, a estrela associada a um Rosto desponta como contrassenso ou como um desastre em relação à lógica do ser. O pensamento de Rosenzweig denuncia o fato de a ontologia acabar refém ou presa às malhas de um êxtase e, consequentemente, abstrair da existência concreta.

Enfim, no horizonte da ontologia o Espírito na forma de uma compreensão do ser abstrai o corpo de um Rosto, de um Nome Próprio, que diante da morte real e crua resiste ao ser. É, pois, assim que, paradoxalmente, a estrela, um Rosto, brilha como resistência à luz do Ser.

\section{DO ESQUECIMENTO DA PALAVRA-SÍMBOLO À PALAVRA DO OUTRO}

Em segundo lugar, recorda o filósofo judeu-alemão, as antinomias também se fazem sentir devido à exclusão de nosso horizonte real-existencial, da palavra-símbolo, da palavrametáfora por excelência resumida no vocábulo "E" (ROSENZWEIG, 2003, p. 359) que conecta e reconecta mundo "e" homem "e" deus "e" mundo "e" homem "e" deus, e assim, sucessiva e incansavelmente, de modo a dar origem a uma teia de relações reais e linguísticas que jamais elimina a diferença graças à multiplicidade que a constitui sem deixar-se seduzir pela paz do Uno de Parmênides ou pela guerra dos contrários de Heráclito que tende a eliminar a diferença pela força do mais forte sobre o mais fraco.

Em contraposição à visão antiga do uno ou do múltiplo, a palavra "E" nos permite evadir do imaginário filosófico de uma espécie de tentação, seja aquela da tentativa de fusão a 
todo preço entre os diferentes termos - resultando na confusão de línguas -, seja a da ilusão de que a substituição de um termo pelo outro, isto é, de um fundamento por outro, viria a solucionar o problema da dissolução do sentido.

Dito de outra forma, a palavra "E" propicia passar do imaginário sem transcendência de certo tipo de filosofia focada na dialética à simbólica de outra sabedoria da alteridade, pois aquela palavra assegura a real inclusão e a real proteção contra todo tipo de "exclusão" do outro. Ela reforça a ideia de que a exclusão não é senão outra coisa do que a imposição do império da antinomia a fim de esquivar-se da Palavra que sai da boca do outro.

Nesse sentido, a estrela é ao mesmo tempo (sím)bolo e (metá)fora daquilo que em princípio pareceria (im)possível de se manter próximo sem de fato se tocar e se fundir. Afinal, a Palavra de outrem é sempre da ordem de uma intermitência, pois palavra dita aqui, traço, hiato, silêncio, e outra palavra dita acolá. Em seguida, ela se associa a tantas outras palavras de tantos outros rostos, bem como está a exigir ultrapassagens e interrupções nos discursos sintéticos e conclusivos graças ao Rosto cuja palavra é da ordem do infinito.

Além disso, ao insistir que a expressão "E" emerge como uma palavra e não apenas como um signo e que, portanto, não se reduz a mero conectivo necessário e justificável do ponto de vista de uma Linguística da língua, Rosenzweig pretende reforçar a ideia de que essa palavra implode o caráter formal de uma língua segundo suas regras (sintáticas e semânticas), para referi-la à Linguística do Discurso. Pois essa palavra "E" produz literalmente a circulação [sem fechar o círculo] do sentido para além de si mesma, de sorte que a palavra dá origem a uma surpreendente (re)invenção do Desejo graças à ciranda ou à pericorese na qual cada termo da linguagem está a refundar ou ressignificar o sentido do outro, e assim por diante (ROSENZWEIG, 2003, p. 322).

Sobressai, a partir dessa lógica, o fato de o discurso não ter qualquer pretensão de realizar uma síntese ou um consenso e fechar então o círculo da comunicação entre os diferentes termos da intriga do desejo. Graças a isso, diz o filósofo, a palavra inaugura a possibilidade do milagre contra a tentação da idolatria imanente à pretensão de uma ciência sobre a linguagem do Estruturalismo "na qual o humano se torna um avatar" (LEVINAS, 2009, p. 99). Ao invés, a sabedoria da intriga põe em questão a ilusão de um discurso unitário, circular, concebido a partir do universal, do genérico.

Em termos histórico-filosóficos, o advento da palavra "E" está na gênese desse milagre linguístico em meio à perda dos fundamentos. Ela evoca um tipo de abertura que deflagra uma cascata de sucessivas aberturas em torno do sentido [ético] dos outros sentidos, 
pois um termo (mundo-deus-homem) provoca uma fissura, um atravessamento no outro, da mesma forma que o outro termo conduz o anterior e o posterior para fora de si (meta) e, assim, sucessivamente. Disso decorre que a palavra é portadora de uma "alteridade" que abre o discurso para aquém e além do pensamento sintético, circular, a impedir qualquer fechamento sobre si mesmo. Pelo contrário, ele aproxima os termos sem preocupar-se em chegar a um bom termo ou um resultado linguístico pragmático da comunicação.

Nesse sentido, a palavra "E" põe em questão a tentação que ronda continuamente a tradição filosófica moderna em torno do idealismo do Espírito (hegeliano) e da ontologia contemporânea. Se tanto um como o outro se põem a procurar o sentido à luz do conceito ou segundo a fosforescência do Ser - com a irrupção da palavra -, a glória do Rosto, do brilho da estrela, fala para além da linguagem unívoca do Ser. Contrário à exaltação da temporalidade do tempo do aparecer do ser, a Palavra interrompe o Discurso coerente do Espírito de modo a buscar o sentido no apelo ou na interpelação ética do Rosto cuja estrela diz respeito à redenção do mundo e não à manifestação da glória do Ser.

Outra questão fundamental contrária à magia do pensamento se deve à própria estrutura linguística inaugurada pela palavra "E". Ela é ternária e não binária como na dialética do Senhor-Escravo ou como na diferença ontológica Ser/ente da ontologia. Devido a essa maneira de a linguagem aproximar, atravessar e ao mesmo tempo distanciar os termos, mantendo-os em absoluta separação, a dialógica da separação/proximidade se apresenta como uma maneira concreta de interromper as ilusões do Espírito ou a idolatria do Ser-para-morte.

Se, portanto, eles têm a pretensão de repor o Sentido em torno da alteza/abaixamento do ser (como espírito ou como facticidade) porque reivindicam para si o lugar de sobrevoo e do êxtase, o fato é que acabam por se distanciar do concreto, do único, do singular, da protolinguagem em torno “do Sim e do Não de um ser-um-alguma-coisa de outrem”. Eles preferem se ocupar, ambos, cada qual ao seu modo, de referir o sentido ao anônimo da Razão ou do Existir e de vincular o sentido às suas respectivas linguagens totalizantes do conceito ou da verbalidade do ser (ROSENZWEIG, 2003, p. 51).

Ademais, a questão dialógica, e por que não dizer (alter)ológica de um (heteró)logos modo de viver, supõe ter-se de aprender a lidar com o problema visceral da deposição dos fundamentos diante da estrela que cai sobre o alto de nossas cabeças, isto é, sem ceder à tentação da solução mágica da dialética e da diferença ontológica contra as antinomias das quais somos reféns na contemporaneidade. Trata-se de resistir tanto aos subterfúgios do relativismo como à ingenuidade da conciliação do sentido, levando-se em conta que no 
regime da (alter)ologia a linguagem jamais exerce a mera função de mediação ou de meio termo entre os dois outros em vista de encaminhá-los para a referência fora deles, como no Estruturalismo.

A despeito disso nota-se o aparecimento da aporia incontornável. Por um lado, as antinomias - ou/ou - nos conduzem à pulverização dos sentidos; por outro, o Neutro, o terceiro termo que visava a restabelecer o sentido em torno do ser fracassa, pelo fato de o ser se apresentar como a genérica Existência. Daí a necessidade de se voltar ao concreto e à palavra/linguagem "E" como via da dialogia e, portanto, como lugar/linguagem do milagre sem idolatria. Pois, se a antinomia isola os termos, e o Neutro tende a sacrificar as unicidades e orientar a existência a um telos imanente ao ser-no-mundo, a palavra aproxima as unicidades irredutíveis ao Ser. É como se o milagre da palavra pusesse em questão a magia do terceiro (ROSENZWEIG, 2003, p. 69).

O discurso do Ser se apresenta como a possibilidade de decretar o fim das aporias ou das antinomias que tendem a eleger, ora o mundo, ora o homem, ora Deus em nome de uma totalidade. Em contrapartida, na volta ao concreto a palavra se vale da relação entre um "e" outro "e" o terceiro de sorte que o discurso, a comunicação e a linguagem dialógica são radicalmente abertas pela abertura que essa relação marcada pela eleidade dos termos assegura, de modo a resistir ao binarismo ou à antinomia.

\section{A ELEIDADE E O FIM DOS SACRIFÍCIOS HUMANOS}

Há de se recordar que seguindo a lógica da dialogicidade não se aventa o abandono das antinomias por meio da suprassunção do Espírito tampouco pela anfibologia do Dizer/Dito do Ser, porque a lógica que subjaz à unificação dos termos se dá ao sabor do sacrifício das diferenças. E em todo sacrifício no qual se sacrifica a unicidade de cada um em nome da unidade (da igualdade) de gênero, configura-se aí uma violência contra o outro, da mesma forma que se prenuncia a eliminação, o aniquilamento, o assassínio do terceiro. E essa lógica se mostra contraditória bem como inviabiliza terminantemente a possibilidade de enfrentar o problema escatológico do fim de um mundo ou da tragédia, da catástrofe que se abate sobre nós na contemporaneidade. Nessa ótica, resta pouco espaço para a Espera, para o porvir que, em última instância, está a depender única e exclusivamente do advento do messias. 
Em vista de se salvaguardar a outra lógica da palavra "E" que foge do binário a partir da qual o terceiro termo viria solucionar os impasses da separação/relação, urge reabilitar a alteridade associada à figura da estrela em consonância com um Rosto, tendo-se presente que a inclusão e a metáfora de que é herdeira a palavra (abre para a diferença) fazem eclodir a relação como concreção da linguagem da relação (ROSENZWEIG, 2003, p. 323).

Assim, essa palavra pode nos interpelar para além da perplexidade/relativismos da perda dos fundamentos e da catástrofe. Encontra-se precisamente na (u)tópica e nos novos trópicos das tropologias do outro a (im)possibilidade de sair da magia na qual estamos enredados na atualidade. Ela nos encaminha a pensar outramente o sentido como a falar outramente a linguagem. Isso nos remove tanto do lugar habitual atribuído ao Espírito e à Existência como do respectivo discurso coerente (LEVINAS, 1988a, p. 66).

Essas tropologias nos remetem imediatamente à imediação patética graças à relação entre-nós, isto é, entre o eu, outrem e o terceiro. Por um lado, os mantém numa separação abissal, condição exigida para que se preservem as respectivas diferenças de únicos em sua totalidade. Por outro, seguindo a lógica imanente da proximidade, "o entre-nós da relação faz com que os três se aproximem de maneira tangencial uns dos outros evitando-se com isso tanto a solidão bem como a fusão entre eles" (ROSENZWEIG, 2003, p. 325).

Em suma, a catástrofe se revela sintomática em uma cultura sacrificial - pósholocausto - a persistir na contemporaneidade, caso ela não seja tratada pelo novo pensamento do (im)pensável outro ao qual se referia Levinas. Essa enfermidade se deve ao duplo equívoco que a acompanha, a saber, o da idolatria do pensamento sobre a morte/nada e o engodo da linguagem unívoca a serviço do universalismo do ser = pensar ou do pensar sem ser do estruturalismo (LEVINAS 2009, p. 92).

Por sua vez, o contraponto à catástrofe desponta com o surgimento da estrela da redenção ou a redenção anunciada pela estrela, porque oferece um esquematismo absolutamente inédito tal como se nos apresenta um Rosto estelar. E a ética que o contato com a carne do outro prenuncia como redenção antecipa a chegada utópica do reino como "de um novo céu e de novas terras" a depender do outro/palavra.

Marcada por seis pontos imaginários que asseguram a autonomia desses polos ao mesmo tempo em que sugerem uma aproximação entre eles, anuncia-se com isso o aparecimento da figura da estrela. A aproximação entre os polos da estrela se esboça em forma de curvaturas, de sorte que não se tem a pretensão de unir os pontos distantes, tal como sucede no tracejar de linhas retas. Estas visam a preencher os espaços vazios, pois avançam a 
fim de estabelecer o liame complementar entre um polo e outro, enquanto as curvaturas se movem por outra lógica, tratam de aproximar os polos por meio de um tangenciamento sem jamais se tocarem. Disso decorre que a caracterização de um Rosto como uma estrela suscita, por um lado, a aproximação dos polos da relação por meio dessas curvaturas imaginárias; por outro, o Rosto mantém a intangibilidade entre os polos da relação. Trata-se de assegurar que um não se perca e que, respectivamente, o Rosto, a estrela, e a redenção sejam desfigurados, comprometidos, negados em nome da totalidade do saber.

À guisa de conclusão urge dizer que, se é verdade que, por um lado, a palavra que sai da boca do outro dá origem às diversas gramáticas graças às relações que se configuram entre as seis pontas da estrela, por outro, o Rosto aponta para a triangulação da linguagem cuja articulação se dá em torno de dois triângulos sem qualquer pretensão de fechar a circulação da linguagem. Diferente de um círculo, a estrela conta com as arestas que "a constituem como figura inacabada" (ROSENZWEIG, 2003, p. 321). As figuras do Rosto emergem, portanto, dessa lógica ilógica do pensamento estelar cujo fulgor advém da própria glória da palavra do outro. A glória sendo da ordem da palavra infinita em seu por vir não se submete jamais à iluminação do Espírito nem se deixa circunscrever-se à fosforescência do ser. E se o ser como verbalidade ao qual a linguagem se tornou serviçal do ser permite antecipar o fim do discurso como manifestação do ser na temporalidade, seguindo essa lógica o brilho/palavra da estrela do Rosto parece fadado a desaparecer em detrimento da glória do ser. Apesar de tudo, contra toda esperança, a espera e a proximidade pathética do Dizer rosto (LEVINAS, 2009, p. 96) resiste a toda intempérie da linguagem silenciosa do encantamento do ser na contemporaneidade.

\section{REFERENCIAS}

AGAMBEN, Giorgio. $O$ que resta de Auschwitz. $O$ arquivo e a testemunha. Homo Sacer III. São Paulo: Boitempo Editorial, 2008.

BLANCHOT, Maurice. L'espace littéraire. Paris: Gallimard, 2018.

BLANCHOT, Maurice. L'ecriture du desastre. Paris: Gallimard, 1980.

GIRARD, René. O bode expiatório e Deus. Covilhã: Universidade da Beira Interior, 2009.

GISEL, Pierre. Les constellations du croire. Dispositifs hérités, problématisations, destin contemporain. Genève: Labor et Fides, 2009. 
KAFKA, Franz. A metamorfose. São Paulo: Companhia das Letras, 2000.

LEVINAS, Emmanuel. De outro modo que ser ou para lá da essência. Lisboa: Centro de Filosofia da Universidade de Lisboa, 2011.

LEVINAS, Emmanuel. De Deus que vem à ideia. Petrópolis: Vozes, 2002.

LEVINAS, Emmanuel. Ética e infinito. Lisboa: Edições 70, 1988 b.

LEVINAS, Emmanuel. Humanismo do outro homem. Petrópolis: Vozes, 2009.

LEVINAS, Emmanuel. Noms propres. Paris: Fata Morgana, 1976.

LEVINAS, Emmanuel. Totalidade e infinito. Lisboa: Edições 70, 1988a.

LEVI, Primo. É isto um homem? Rio de Janeiro: Rocco, 1988.

MERLEAU-PONTY, Maurice. Conversas - 1948. São Paulo: Martins Fontes, 2004.

MUKASONGA, Scholastique. Baratas. São Paulo: Editora Nós, 2018.

ROSENZWEIG, Franz. L’étoile de la Rédemption. Paris: Seuil, 2003.

SOUZA, Ricardo Timm de. Adorno \& Kafka: paradoxos do singular. Passo Fundo: IFIBE, 2010.

VIVEIROS DE CASTRO, Eduardo. Metafísicas canibais: elementos para uma antropologia pós-estrutural. São Paulo: Cosac Naify, 2015. 